\title{
Surface Modification of Electrospun Polycaprolactone Nanofiber Meshes by Plasma Treatment to Enhance Biological Performance
}

\author{
Albino Martins, Elisabete D. Pinho, Susana Faria, Iva Pashkuleva, Alexandra \\ P. Marques, Rui L. Reis, and Nuno M. Neves*
}

\begin{abstract}
$\boldsymbol{A}$ critical aspect in the development of biomaterials is the optimization of their surface properties to achieve an adequate cell response. In the present work, electrospun polycaprolactone nanofiber meshes (NFMs) are treated by radio-frequency $(R F)$ plasma using different gases ( $\mathrm{Ar}$ or $\mathrm{O}_{2}$ ), power (20 or $30 \mathrm{~W}$ ), and exposure time (5 or $10 \mathrm{~min}$ ). Morphological and roughness analysis show topographical changes on the plasma-treated NFMs. X-ray photoelectron spectroscopy (XPS) results indicate an increment of the oxygen-containing groups, mainly $-\mathrm{OH}$ and $-\mathrm{C}=\mathrm{O}$, at the plasma-treated surfaces. Accordingly, the glycerol contact angle results demonstrate a decrease in the hydrophobicity of plasma-treated meshes, particularly in the $\mathrm{O}_{2}$-treated ones. Three model cell lines (fibroblasts, chondrocytes, and osteoblasts) are used to study the effect of plasma treatments over the morphology, cell adhesion, and proliferation. A plasma treatment with $\mathrm{O}_{2}$ and one with Ar are found to be the most successful for all the studied cell types. The influence of hydrophilicity and roughness of those NFMs on their biological performance is discussed. Despite the often claimed morphological similarity of NFMs to natural extracellular matrixes, their surface properties contribute substantially to the cellular performance and therefore those should be optimized.
\end{abstract}

\author{
Keywords: \\ - biodegradable materials \\ - biological activity \\ - nanofibers \\ - surface analysis \\ - wetting
}

\section{Introduction}

Biomaterials can be used to tailor the biophysical and biochemical milieus that direct cellular behavior and function into the desired regeneration of tissues. ${ }^{[1]}$ Thus, they may play a significant role in the modern strategies of regenerative medicine and tissue engineering. A number of naturally derived polymers, such as collagen, gelatine, albumin, chitosan, and starch, have already been shown to have properties relevant to many biomedical applications. ${ }^{[2]}$
[*] Prof. N. M. Neves, A. Martins, E. D. Pinho, Dr. I. Pashkuleva Dr. A. P. Marques, Prof. R. L. Reis

3B's Research Group - Biomaterials, Biodegradables and Biomimetics

Department of Polymer Engineering, University of Minho Headquarters of the European Institute of Excellence on Tissue Engineering and Regenerative Medicine

AvePark, Zona Industrial da Gandra, S. Cláudio do Barco, 4806-909 Caldas das Taipas, Guimarães (Portugal)

E-mail: nuno@dep.uminho.pt; amartins@dep.uminho.pt
Prof. N. M. Neves, A. Martins, E. D. Pinho, Dr. I. Pashkuleva Dr. A. P. Marques, Prof. R. L. Reis

IBB - Institute for Biotechnology and Bioengineering PT Government Associated Laboratory, Braga (Portugal)

Dr. S. Faria

Research Centre Officina Mathematica, Department of Mathematics for Science and Technology, University of Minho Campus de Azurém, 4800-058 Guimarães (Portugal)

DOI: $10.1002 / \mathrm{smll} .200801648$ 
However, biodegradable polymers belonging to the aliphatic polyester family currently represent the most attractive group of polymers that meet various medical and physical demands for safe clinical applications. ${ }^{[3]}$ This is mainly due to their biocompatibility, acceptable degradation rates, and versatility regarding physical and chemical properties. ${ }^{[4]}$ Undoubtedly, three of the most significant members of the aliphatic polyester family are polyglycolide (PGA), polylactide (PLA), and poly( $\varepsilon$-caprolactone) (PCL). Among them, PCL is the most hydrophobic and degrades by hydrolysis of its ester bonds under physiological conditions at a much slower rate than PGA and PLA. ${ }^{[5]}$ It has been shown that PCL is biocompatible for some applications ${ }^{[4,6]}$ and it has exceptional ability to form compatible blends and copolymers with a wide range of other polymers, resulting in materials with unique ranges of properties. ${ }^{[5,7]}$

Much attention has also been devoted to the electrospinning technique as an innovative processing method for biodegradable polymers. ${ }^{[8-10]}$ It is a versatile technique allowing for the production of polymeric ultrafine fibers with diameters ranging from a few micrometers down to tens of nanometers. ${ }^{[10,11]}$ Besides the dimensional reduction to the nanolevel, the ability of this technique to shape materials with morphologies mimicking the extracellular matrix (ECM) of many tissues in the body is relevant to control cell affinity and adhesion. ${ }^{[9,12]}$ The cell behavior on nanostructured surface materials has been extensively studied. ${ }^{[12,13]}$ Indeed, an enhanced cell attachment and proliferation was observed on nanostructured surfaces in comparison to the microstructured surfaces. ${ }^{[14]}$

An ideal biomaterial should have adequate bulk properties, while the surface should have enhanced affinity with cells. As it is very difficult to design biomaterials combining bulk properties and surface properties, a common approach is to produce biomaterials with adequate bulk properties followed by a surface modification to enhance the surface properties. The surface modification of a biomaterial can be achieved by various techniques, including treatments by flame, corona discharge, plasma, photons, electron beam, ion beam, X-ray, and $\gamma$-ray. ${ }^{[15,16]}$ In the present study, plasma treatment was the selected process to modify the surfaces of electrospun PCL nanofiber meshes (NFMs). Plasma treatment is a versatile and effective method for modifying the surface properties or introducing desired chemical groups at the surface of a material without affecting its bulk properties. ${ }^{[15,17,18]}$ The most apparent effects of plasma treatment are surface cleaning, microetching, and surface activation (attachment of chemical groups, modification of surface charge, increase of the surface free energy). ${ }^{[18]}$ A common application of this technique is to improve the surface hydrophilicity by forming oxygencontaining groups at the surface of the materials. ${ }^{[19-21]}$ In recent years, plasma surface modifications have been used very intensively in the field of biomedical materials research. ${ }^{[15,17,18]}$ Typical examples of plasma-modified polymers used for cell culture experiments are Primaria ${ }^{\circledR}$ and tissue culture polystyrene (TCPS). Both types of polymer surfaces induce good cell adhesion in vitro, but are not able to fulfill the requirements for a prosthetic implant material. ${ }^{[22]}$

The aim of the present study was to produce electrospun PCL NFMs and modify their surfaces in order to improve the adhesion and proliferation of cells. Untreated and plasma modified NFMs were characterized using various surfacesensitive techniques, namely scanning electron microscopy (SEM), interferometric optical profilometry, contact angle measurement, and X-ray photoelectron spectroscopy (XPS). These techniques enable the evaluation of changes in surface topography, hydrophilicity, and surface chemistry as a result of the treatment. Different assays were used to characterize the effects of the plasma treatments over fibroblast, chondrocyte, and osteoblastic cell lines when seeded on the plasma-treated and untreated PCL NFMs. The biological relevance of each plasma treatment was assessed, analyzing the cell attachment, morphology, viability, and proliferation. To the best of our knowledge, this is the first systematic study where different plasma treatment conditions for electrospun biodegradable NFM modification was reported with respect to the performance of different cell types, and aiming at the regeneration of different tissues.

\section{Results}

\subsection{Morphological Characterization of Plasma-Treated Electrospun Nanofibers}

The SEM photomicrographs of the untreated and plasmatreated electrospun PCL NFMs are shown in Figure 1. The $\mathrm{O}_{2}$-plasma treatments analyzed by SEM revealed that the $10 \mathrm{~min}$ treatment with $30 \mathrm{~W}$ power induced melting of the thinner nanofibers (Figure 1B). This effect creates more open space between the fibers still present in the mesh. When the exposure time or the power was reduced, fibers with irregular morphology and nonuniform diameter and spherical terminated ends were observed. The melting of thinner fibers was also observed when the working atmosphere was changed

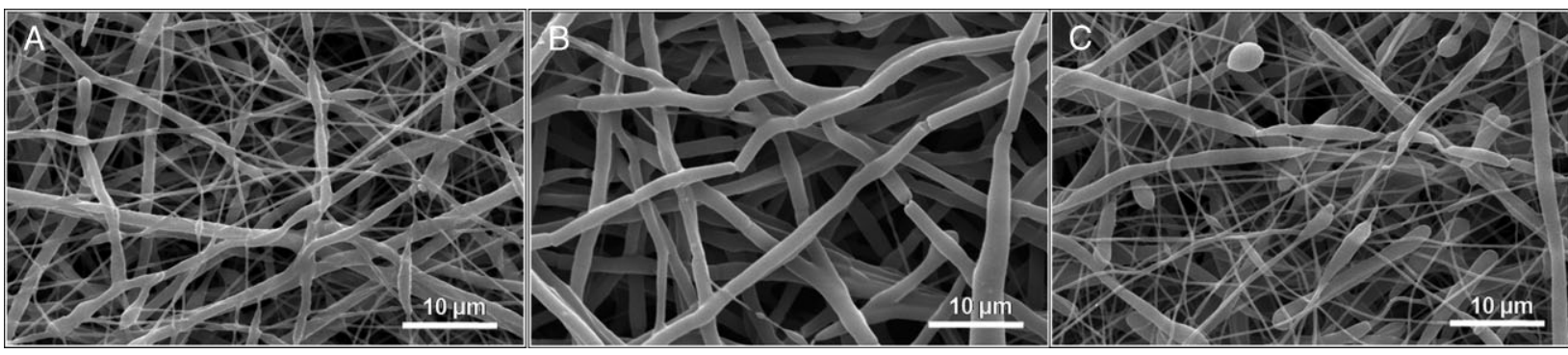

Figure 1. SEM micrographs of untreated and plasma-treated PCL NFMs. A) Untreated PCL NFM. B) $\mathrm{O}_{2}$ at $30 \mathrm{~W}$ for $10 \mathrm{~min}$. C) Ar at $30 \mathrm{~W}$ for $10 \mathrm{~min}$. 
Table 1. Surface roughness parameters $(\mu \mathrm{m})$ of some plasma-treated and untreated electrospun PCL NFMs. $R_{\mathrm{a}}$ : roughness average; $R_{\mathrm{q}}$ : RMS roughness.

\begin{tabular}{lccccccccc}
\hline $\begin{array}{l}\text { Roughness } \\
\text { Parameters }\end{array}$ & Untreated & $\begin{array}{c}\mathrm{O}_{2} 30 \mathrm{~W}, \\
10 \mathrm{~min}\end{array}$ & $\begin{array}{c}\mathrm{O}_{2} 30 \mathrm{~W}, \\
5 \mathrm{~min}\end{array}$ & $\begin{array}{c}\mathrm{O}_{2} 20 \mathrm{~W}, \\
10 \mathrm{~min}\end{array}$ & $\begin{array}{c}\mathrm{O}_{2} 20 \mathrm{~W}, \\
5 \mathrm{~min}\end{array}$ & $\begin{array}{c}\mathrm{Ar} 30 \mathrm{~W}, \\
10 \mathrm{~min}\end{array}$ & $\begin{array}{c}\mathrm{Ar} 30 \mathrm{~W}, \\
5 \mathrm{~min}\end{array}$ & $\begin{array}{c}\mathrm{Ar} 20 \mathrm{~W}, \\
10 \mathrm{~min}\end{array}$ & $\begin{array}{c}\mathrm{Ar} 20 \mathrm{~W}, \\
5 \mathrm{~min}\end{array}$ \\
\hline$R_{\mathrm{a}}$ & 2.01 & 1.40 & 2.26 & 2.65 & 2.51 & 1.86 & 1.97 & 2.05 & 4.72 \\
$R_{\mathrm{q}}$ & 2.49 & 1.95 & 2.81 & 3.30 & 3.31 & 2.41 & 2.51 & 2.63 & 6.55 \\
\hline
\end{tabular}
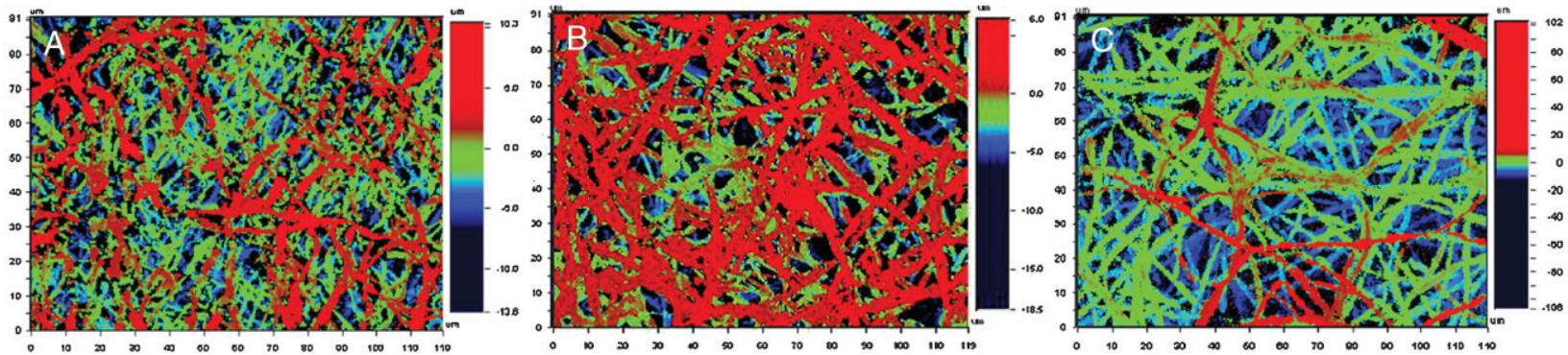

Figure 2. Optical profilometry images of the untreated PCL NFMs (A), $\mathrm{O}_{2}$-treated at $30 \mathrm{~W}$ for $10 \mathrm{~min}$ (B), Ar-treated at $20 \mathrm{~W}$ for 5 min (C).

to Ar. The exception was the treatment at $30 \mathrm{~W}$ power and 10 min exposure in which the nanofibers appear with blunted ends (Figure 1C).

The surface roughness parameters of the untreated and plasma-treated electrospun NFMs are shown in Table 1. The average surface roughness, $R_{\mathrm{a}}$, of untreated NFM was $2.01 \mu \mathrm{m}$ and its surface profile obtained in interferometric optical profilometry is presented in Figure 2A. Generally, for the conditions involving higher power and longer exposure times, the surface of the PCL NFM becomes smoother with an average roughness of $1.40 \mu \mathrm{m}$ for $\mathrm{O}_{2}$-plasma (Figure 2B) and $1.86 \mu \mathrm{m}$ for Ar plasma. Conversely, the lower power and shorter exposure time resulted in a rougher surface, with a $R_{\mathrm{a}}$ value of $2.51 \mu \mathrm{m}$ in the $\mathrm{O}_{2}$-plasma treatment and $4.72 \mu \mathrm{m}$ in the Ar-plasma treatment (Figure 2C).

\subsection{Hydrophilicity of Plasma-Treated Electrospun Nanofibers}

Contact angle measurements for the untreated and plasma-treated electrospun PCL NFMs were performed to determine the effect of treatments on the surface hydrophilicity. The measurements were carried out at different time periods: the initial time points are the most important because they reflect the moment when the materials come into contact with body fluids. Measurements for longer times were intended to evaluate the equilibrium surface wettability. A direct comparison between each couple-modified versus untreated-PCL NFMs was performed. A Kruskal-Wallis statistical analysis test was performed for each couple and time period, and statistically significant differences were obtained $(p<0.00001)$. Dunnett's test for multiple comparisons was used to determine the plasma treatments that led to statistically significant differences when compared with untreated NFMs.

Initially, the contact angle measurements were performed using water. Untreated PCL NFMs demonstrated a water contact angle of $130^{\circ}$ (data not shown), and this value was shown to be stable during the studied time periods. Considering the water contact angle of Ar-treated samples, a decrease of $20^{\circ}$ was observed (data not shown), that is, the surfaces became less hydrophobic. Oxygen-treated NFMs presented water contact angles below $20^{\circ}$, which could not be detected by the high speed camera. To overcome this difficulty, a highly viscous polar liquid, glycerol, was used instead of water to characterize the differences in contact angle of the surface-modified NFMs.

As can be observed in Figure 3, $\mathrm{O}_{2}$-plasma treated NFMs presented significantly smaller contact angles than untreated NFMs $(p<0.01)$. The only exception was the treatment with $\mathrm{O}_{2}$ at $20 \mathrm{~W}$ for $5 \mathrm{~min}$. Conversely, the Ar-treated NFM at $30 \mathrm{~W}$ for $10 \mathrm{~min}$ also presented significantly lower values of contact angle $(p<0.01)$ when compared to untreated PCL NFMs. The combined effect of power and exposure time on the surface hydrophilicity should be highlighted: $30 \mathrm{~W}$ and $10 \mathrm{~min}$ exposure resulted in the most hydrophilic surface, while $20 \mathrm{~W}$ and $5 \mathrm{~min}$ did not show any significant difference in hydrophilicity. Additionally, the drop spreading profiles changed for the different plasma treatments in accordance with the results presented before. Thus, it becomes clear that the different surface treatments have significant effects on the hydrophilicity of the NFMs.

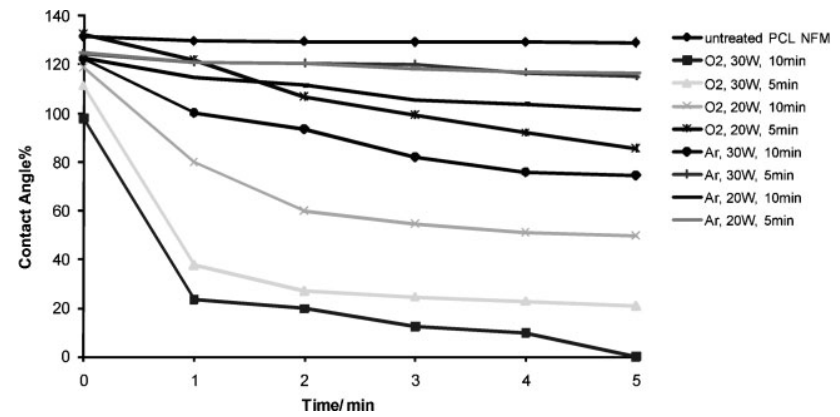

Figure 3. Glycerol contact angle values of untreated and plasmamodified PCL NFMs as a function of time. 
Table 2. Elemental composition of some plasma-treated and untreated electrospun PCL NFMs. C: carbon; O: oxygen.

\begin{tabular}{lccccccccc}
\hline Elements & Untreated & $\begin{array}{c}\mathrm{O}_{2} 30 \mathrm{~W}, \\
10 \mathrm{~min}\end{array}$ & $\begin{array}{c}\mathrm{O}_{2} 30 \mathrm{~W}, \\
5 \mathrm{~min}\end{array}$ & $\begin{array}{c}\mathrm{O}_{2} 20 \mathrm{~W}, \\
10 \mathrm{~min}\end{array}$ & $\begin{array}{c}\mathrm{O}_{2} 20 \mathrm{~W}, \\
5 \mathrm{~min}\end{array}$ & $\begin{array}{c}\mathrm{Ar} 30 \mathrm{~W}, \\
10 \mathrm{~min}\end{array}$ & $\begin{array}{c}\operatorname{Ar} 30 \mathrm{~W}, \\
5 \mathrm{~min}\end{array}$ & $\begin{array}{c}\operatorname{Ar} 20 \mathrm{~W}, \\
10 \mathrm{~min}\end{array}$ & $\begin{array}{c}\mathrm{Ar} 20 \mathrm{~W} \text {, } \\
5 \mathrm{~min}\end{array}$ \\
\hline $\mathrm{C}$ & 80.5 & 75.3 & 70.7 & 77.0 & 79.0 & 82.2 & 82.6 & 73.1 & 72.2 \\
$\mathrm{O}$ & 19.0 & 23.9 & 27.7 & 22.9 & 19.9 & 16.7 & 16.5 & 23.3 & 22.7 \\
C/O ratio & 4.24 & 3.15 & 2.55 & 3.36 & 3.96 & 4.92 & 5.00 & 3.13 & 3.18 \\
\hline
\end{tabular}

\subsection{Chemical Composition of Plasma-Treated Electrospun Nanofibers}

XPS was used to analyze the surface chemistry of electrospun PCL NFMs before and after plasma treatment. As expected and according to the chemical structure of PCL, the XPS analysis of the untreated NFM indicated that the surface was dominated by carbon $(80.5 \%)$ and oxygen $(19.0 \%)$ species (Table 2). Generally, the elemental composition analysis of the plasma-treated samples showed a decrease of carbon content, probably due to the melting process. The oxygen content increases because of the surface oxidation. The exceptions were the PCL NFMs treated with Ar atmosphere at $30 \mathrm{~W}$ for 10 and $5 \mathrm{~min}$, where the carbon content was enhanced. The melting process was more pronounced in the NFMs treated with Ar at lower power, as well as with $\mathrm{O}_{2}$ at $30 \mathrm{~W}$ for 10 and $5 \mathrm{~min}$. The increment of oxygen, depending on the plasma treatment, oscillates between $19.9 \%$, for the $\mathrm{O}_{2}$-plasma treatment at $20 \mathrm{~W}$ for $5 \mathrm{~min}$, and $27.7 \%$ for the $\mathrm{O}_{2}$ treatment at $30 \mathrm{~W}$ for $5 \mathrm{~min}$. The $\mathrm{C} / \mathrm{O}$ ratio decreases in all conditions of plasma treatment with the exceptions already mentioned.

High-resolution peak analysis of carbon 1s (C1s) at the surface was performed for both untreated and plasma-treated PCL NFMs to determine the chemical functional groups present at the surface. All studied materials exhibited three components of the $\mathrm{C} 1 \mathrm{~s}$ core level peak, which correspond to the aliphatic carbon bonds $(-\mathrm{C}-\mathrm{C}-$ or $-\mathrm{C}-\mathrm{H})$, carbon single bonded to oxygen $(-\mathrm{C}-\mathrm{OH}$ or $-\mathrm{C}-\mathrm{O}-)$, and carbonyl functional groups $(-\mathrm{C}=\mathrm{O})$ located at approximately 285 , 287, and $289 \mathrm{eV}$, respectively (Figure 4). As was expected, considerable differences were detected in the intensity of these peaks for the untreated and plasma-treated electrospun PCL NFMs (e.g., $\mathrm{O}_{2}$ treatment at $30 \mathrm{~W}$ for $5 \mathrm{~min}$ ). Thus, the XPS analyses confirmed that the plasma treatments lead to different surface chemistry, which in turn affects the wettability and, consequently, the cell attachment.

\subsection{Cellular Performance over Plasma-Treated Electrospun Nanofibers}

The morphology of the cells cultured on untreated and plasma-treated electrospun PCL NFMs was examined by SEM. For comparative purposes, biological studies were also performed in TCPS coverslips as an optimized substrate for 2D cell culture.
These observations were conducted in the first day after cell culture, because the alterations of the surface induced by the plasma treatments have a major influence at the beginning of the cell adhesion process. SEM micrographs of the direct contact assay with fibroblast-like cells showed a typical spindle-shape morphology of cells cultured on Ar-treated PCL NFMs at $30 \mathrm{~W}$ for $5 \mathrm{~min}$ and at $20 \mathrm{~W}$ for $10 \mathrm{~min}$ (Figure 5I and J). Cells were observed to be dispersed and stretched at the surface of the both plasma-treated and untreated meshlike fibrous structure. The round shape of the chondrocyte-like cells was only kept on untreated PCL NFMs (Figure 6C). Poor chondrocyte attachment was observed on PCL NFMs subjected to plasma-treatment with $\mathrm{O}_{2}$ at $30 \mathrm{~W}$ for $10 \mathrm{~min}$ and $\mathrm{Ar}$ at $30 \mathrm{~W}$ for $10 \mathrm{~min}$ (Figure 6D and $\mathrm{H}$ ), which is understandable since those cells tend to prefer hypoxic environments. On the $\mathrm{O}_{2}$-treated NFMs at $20 \mathrm{~W}$ for $10 \mathrm{~min}$, Ar-treated at $30 \mathrm{~W}$ for $5 \mathrm{~min}$ and at $20 \mathrm{~W}$ for $10 \mathrm{~min}$, the cells presented a flattened morphology, covering almost all the available surface of the meshes. SEM micrographs from the assays with osteoblast-like cells demonstrated that the 2D PCL solvent-cast membrane induces the maintenance of the cell morphology (i.e., cuboid shape) (Figure 7B), as well as on the TCPS surface (Figure 7A). The largest amount of cells was observed on the NFMs treated with $\mathrm{O}_{2}$ at $20 \mathrm{~W}$ for $10 \mathrm{~min}$, Ar at $30 \mathrm{~W}$ for $5 \mathrm{~min}$, and $\mathrm{Ar}$ at $20 \mathrm{~W}$ for $10 \mathrm{~min}$, forming a continuous layer of spread cells. For all the other plasmatreated samples, the cells adhered and interacted with the nanofibrous structure, spreading over the surface.

A metabolic activity-based (MTS) assay was used to determine cell viability of the three cell types along the testing periods on the different studied surfaces. For these assays, a
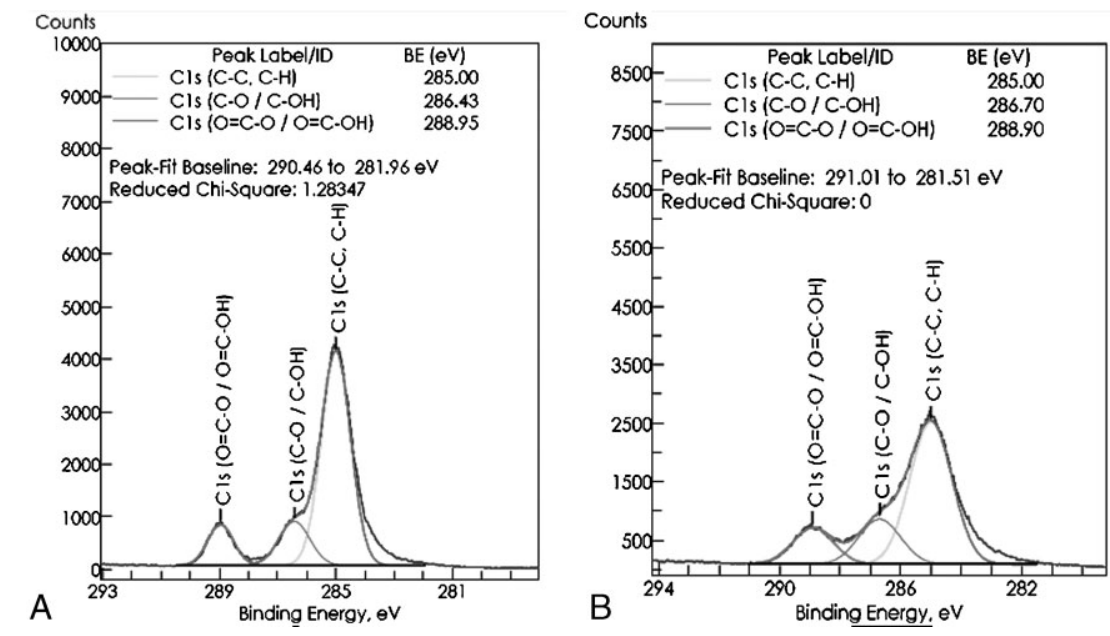

Figure 4. High resolution $\mathrm{C} 1 \mathrm{~s}$ core level signals of untreated $(\mathrm{A})$ and $\mathrm{O}_{2}$-treated electrospun PCL NFMs at $30 \mathrm{~W}$ for $5 \mathrm{~min}(\mathrm{~B})$. 


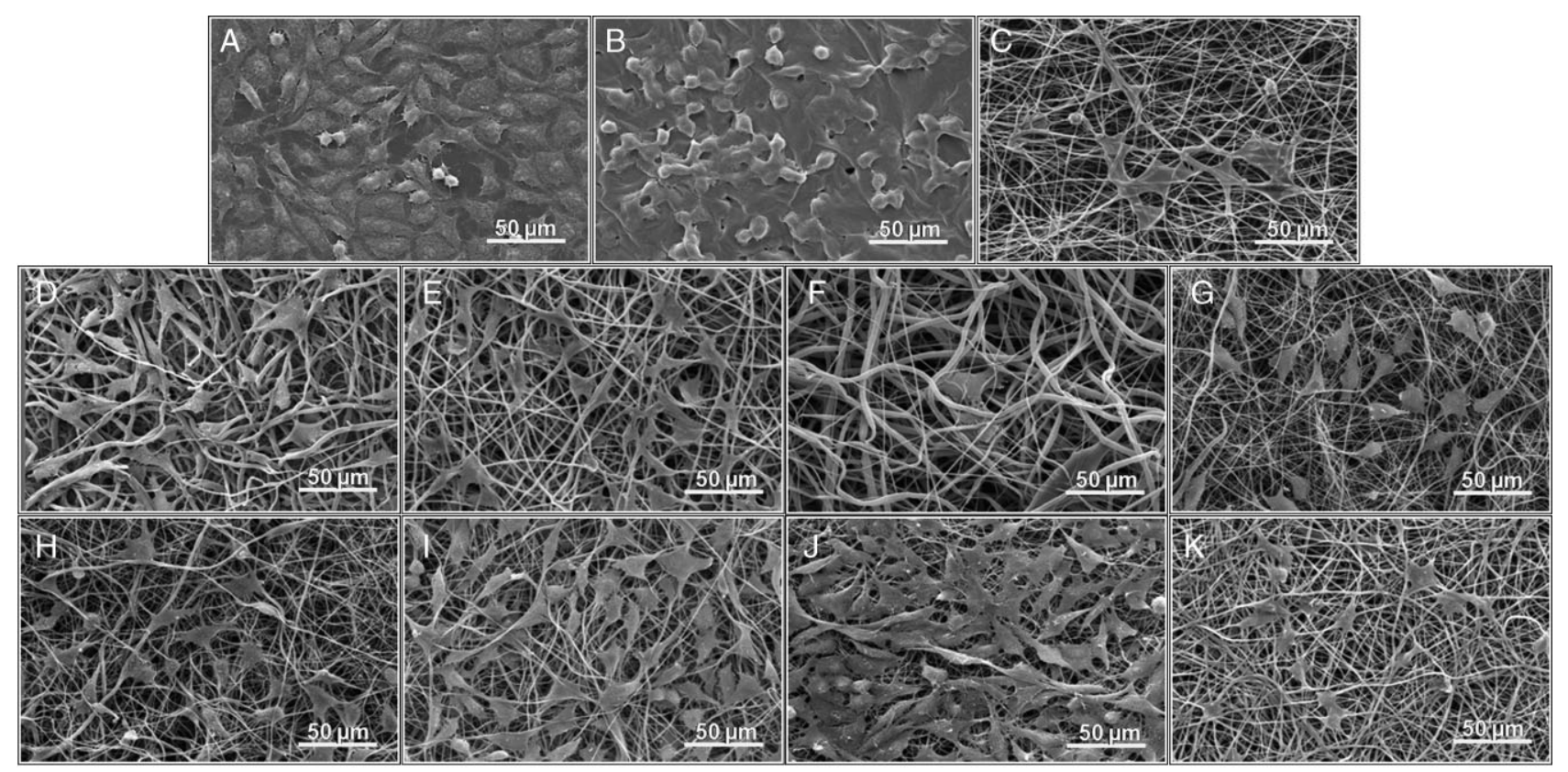

Figure 5. SEM micrographs of $L 929$ cells growing onto untreated and plasma-treated PCL NFMs, after 1 day of culture. A) TCPS. B) PCL sovent-cast membrane. C) Untreated PCL NFM. D) $\mathrm{O}_{2}$ at $30 \mathrm{~W}$ for $10 \mathrm{~min}$. E) $\mathrm{O}_{2}$ at $30 \mathrm{~W}$ for $5 \mathrm{~min}$; F) $\mathrm{O}_{2}$ at $20 \mathrm{~W}$ for $\left.10 \mathrm{~min} ; \mathrm{G}\right) \mathrm{O}_{2}$ at $20 \mathrm{~W}$ for $5 \mathrm{~min}$; H) Ar at $30 \mathrm{~W}$ for $10 \mathrm{~min}$; I) Ar at $30 \mathrm{~W}$ for $5 \mathrm{~min}$; J) Ar at $20 \mathrm{~W}$ for $10 \mathrm{~min}$; K) Ar at $20 \mathrm{~W}$ for $5 \mathrm{~min}$.

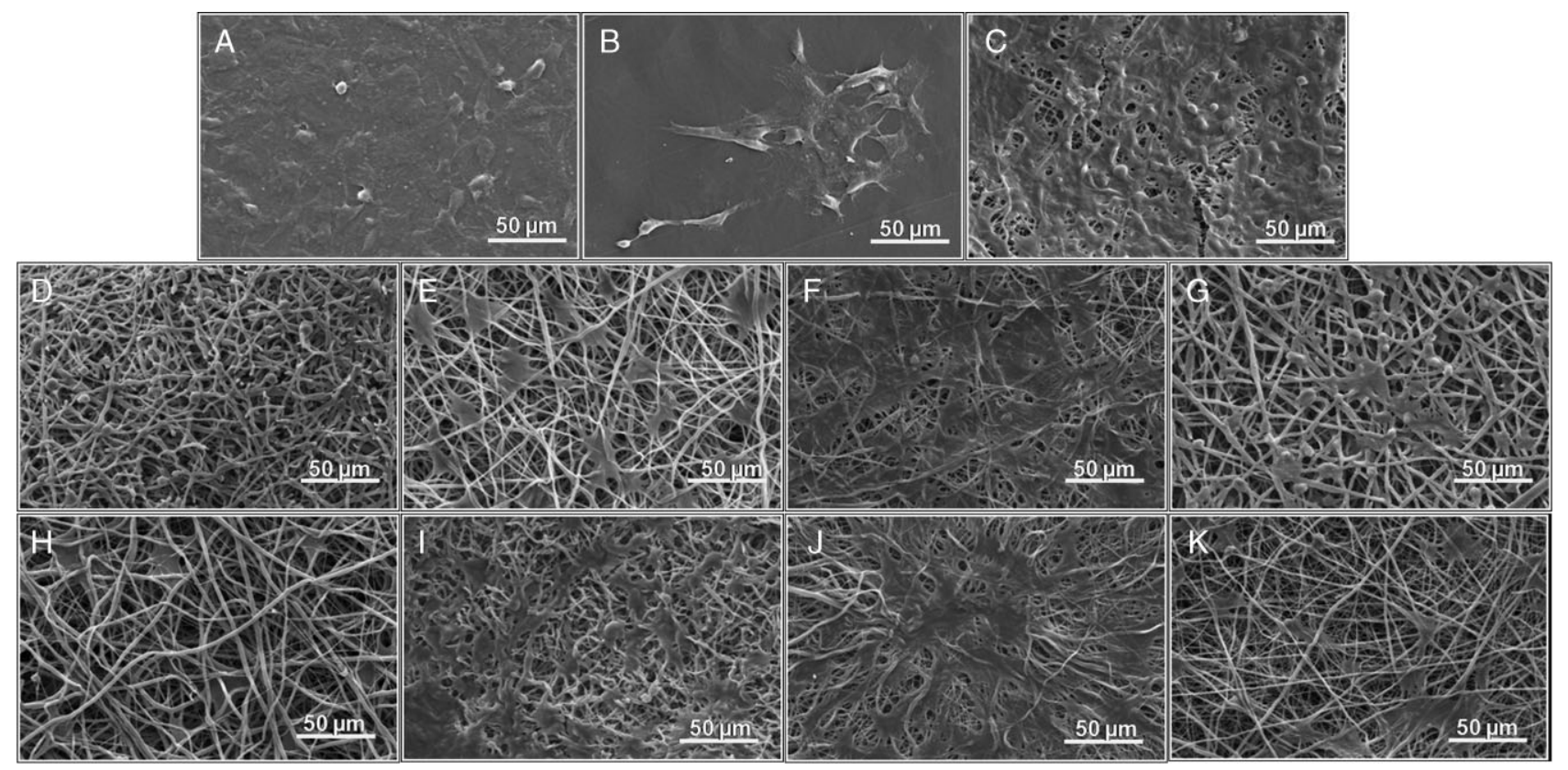

Figure 6. SEM micrographs of ATDC5 cells growing onto untreated and plasma-treated PCL NFMs, after 1 day of culture. A) TCPS. B) PCL sovent-cast membrane. C) Untreated PCL NFM. D) $\mathrm{O}_{2}$ at $30 \mathrm{~W}$ for $10 \mathrm{~min}$. E) $\mathrm{O}_{2}$ at $30 \mathrm{~W}$ for $5 \mathrm{~min}$. F) $\mathrm{O}_{2}$ at $20 \mathrm{~W}$ for $10 \mathrm{~min}$. G) $\mathrm{O}_{2}$ at $20 \mathrm{~W}$ for $5 \mathrm{~min}$. H) Ar at $30 \mathrm{~W}$ for $10 \mathrm{~min}$. I) Ar at $30 \mathrm{~W}$ for $5 \mathrm{~min}$. J) Ar at $20 \mathrm{~W}$ for $10 \mathrm{~min}$. K) Ar at $20 \mathrm{~W}$ for $5 \mathrm{~min}$.

standard TCPS surface was used as a control. For each cell type and culture period, the Kruskal-Wallis test was carried out in order to evaluate significant differences $(p<0.00001)$ between the studied surfaces in terms of cell activity. Additionally, a Dunnett's test for multiple comparisons was performed to determine which plasma treatment has a significant influence on the cell behavior when compared to standard TCPS. The results are shown in Figures 8-10.
In the case of the fibroblastic cell type, the statistical analysis demonstrated that PCL NFMs modified by $\mathrm{O}_{2}$-plasma at $30 \mathrm{~W}$ for $10 \mathrm{~min}$ and at $20 \mathrm{~W}$ for $10 \mathrm{~min}$ are not appropriate substrates for cell adhesion $(p<0.01)$ considering their values of cell viability after 1 day of culture (Figure 8 ). The other plasma treatments did not present statistically significant differences when compared with the untreated PCL NFMs or the TCPS. After 3 days of culture, the NFMs treated with $\mathrm{O}_{2}$ at 


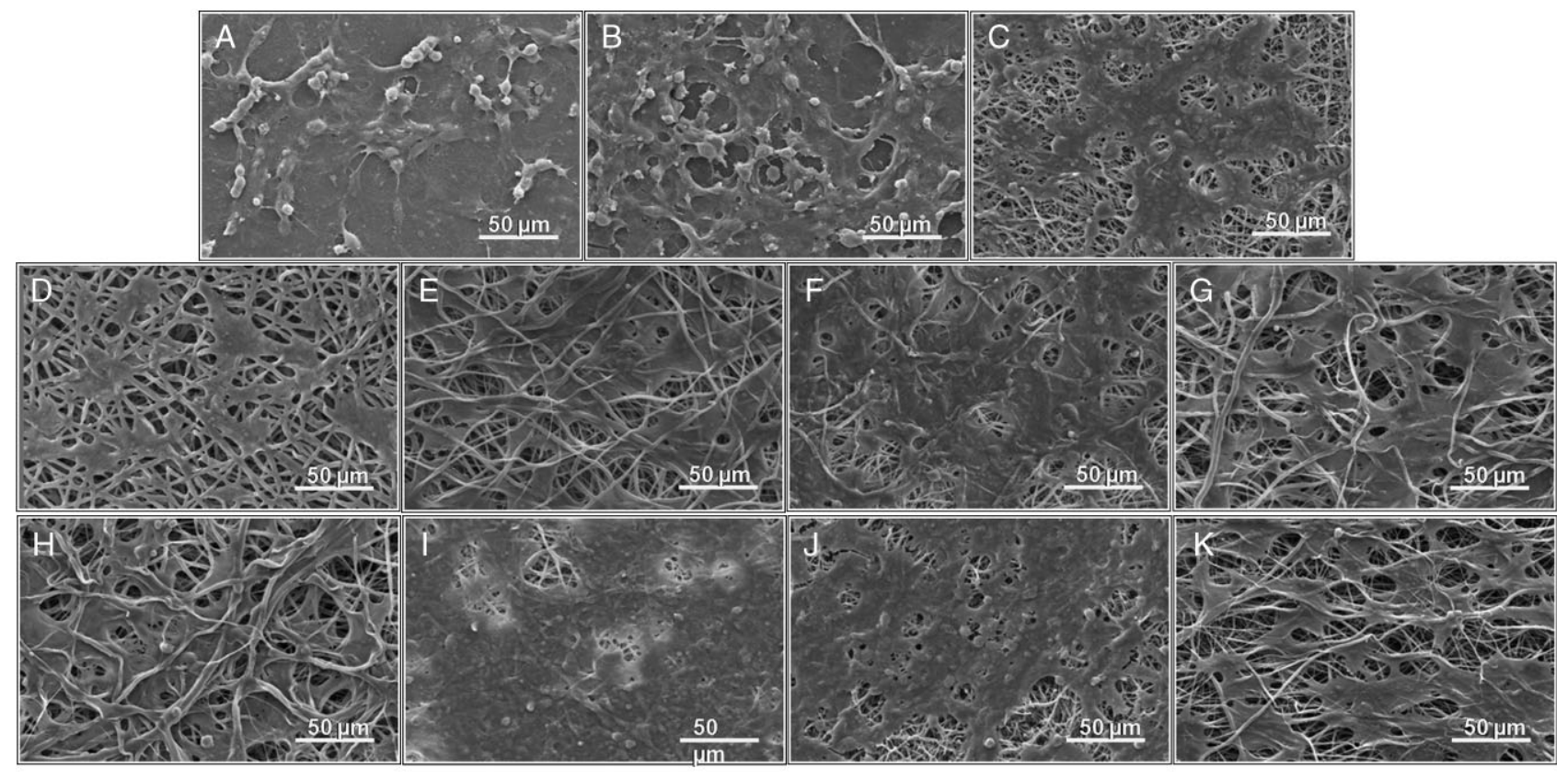

Figure 7. SEM micrographs of Saos-2 cells growing onto untreated and plasma-treated PCL NFMs, after 1 day of culture. A) TCPS. B) PCL sovent-cast membrane. C) Untreated PCL NFM. D) $\mathrm{O}_{2}$ at $30 \mathrm{~W}$ for $10 \mathrm{~min}$. E) $\mathrm{O}_{2}$ at $30 \mathrm{~W}$ for $5 \mathrm{~min}$. F) $\mathrm{O}_{2}$ at $20 \mathrm{~W}$ for $\left.10 \mathrm{~min} . \mathrm{G}\right) \mathrm{O}_{2}$ at $20 \mathrm{~W}$ for $5 \mathrm{~min}$. H) Ar at $30 \mathrm{~W}$ for $10 \mathrm{~min}$. I) $\mathrm{Ar}$ at $30 \mathrm{~W}$ for $5 \mathrm{~min}$. J) Ar at $20 \mathrm{~W}$ for $10 \mathrm{~min}$. K) Ar at $20 \mathrm{~W}$ for $5 \mathrm{~min}$.
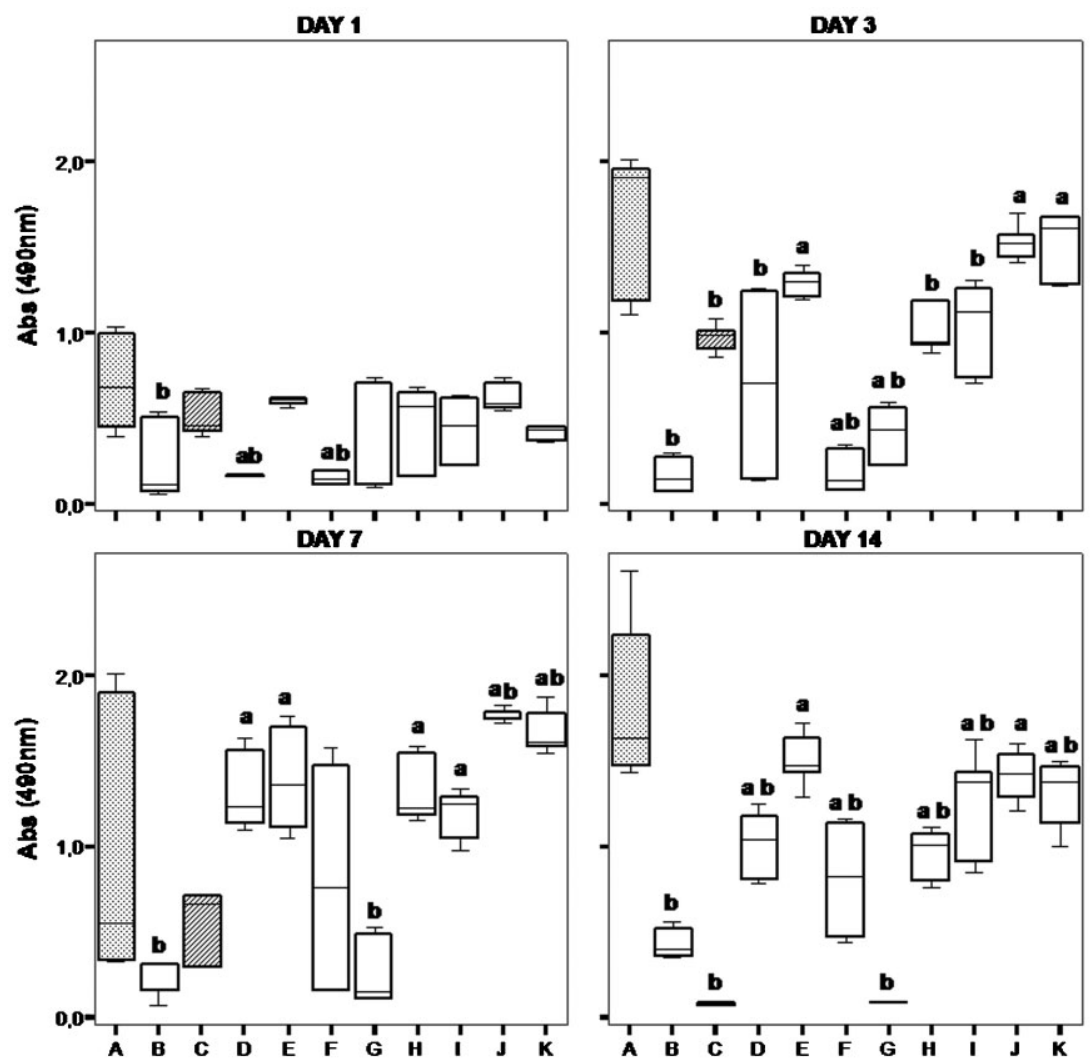

Figure 8. Box plot of MTS assay results for fibroblasts (L929 cell line) cultured on untreated and plasma-treated PCL NFMs for 1, 3, 7, and 14 days. A) TCPS. B) PCL sovent-cast membrane. C) Untreated PCL NFM. D) $\mathrm{O}_{2}$ at $30 \mathrm{~W}$ for $10 \mathrm{~min}$. E) $\mathrm{O}_{2}$ at $30 \mathrm{~W}$ for 5 min. F) $\mathrm{O}_{2}$ at $20 \mathrm{~W}$ for 10 min. G) $\mathrm{O}_{2}$ at $20 \mathrm{~W}$ for $5 \mathrm{~min}$. H) Ar at $30 \mathrm{~W}$ for $10 \mathrm{~min}$. I) Ar at $30 \mathrm{~W}$ for $5 \mathrm{~min}$. J) Ar at $20 \mathrm{~W}$ for 10 min. K) Ar at $20 \mathrm{~W}$ for $5 \mathrm{~min}$. Data were analyzed nonparametrically by Kruskal-Wallis test followed by Dunnett's test for multiple comparisons. a) $p<0.01$ versus untreated PCL NFM. b) $p<0.01$ versus TCPS.
$30 \mathrm{~W}$ for $5 \mathrm{~min}$, or Ar atmosphere at $20 \mathrm{~W}$ for 10 and $5 \mathrm{~min}$ presented statistically significant higher values of cell viability $(p<0.01)$ when compared to those observed for the untreated samples. However, those values were very similar to that observed for the TCPS. At 7 days of fibroblast culture, all Ar-treated samples presented significantly higher values of cell viability than untreated PCL NFMs $(p<0.01)$. When those values were compared with ones obtained for TCPS, only the Ar-plasma treatments at $20 \mathrm{~W}$ revealed a significant difference $(p<0.01)$. At this period of culture, the $\mathrm{O}_{2}$-treated NFMs at $30 \mathrm{~W}$ for 10 and $5 \mathrm{~min}$ also presented significantly higher values than untreated PCL NFMs $(p<0.01)$, but they did not differ from the TCPS. For longer culture periods (14 days), the $\mathrm{O}_{2}$-plasma treatment at $30 \mathrm{~W}$ for $5 \mathrm{~min}$ and the Ar treatment at $20 \mathrm{~W}$ for $10 \mathrm{~min}$ presented similar fibroblast viability to standard TCPS. All the other plasma treatments resulted in lower viability than TCPS $(p<0.01)$. However, a significantly higher cell viability was measured when compared to untreated PCL NFMs. Overall, the plasma-modified NFMs with $\mathrm{O}_{2}$ at $30 \mathrm{~W}$ for $5 \mathrm{~min}$ and with Ar at $20 \mathrm{~W}$ for 10 and $5 \mathrm{~min}$ are the best substrates for fibroblastic proliferation for shorter (3 days) culture times, with cellular activity similar to standard TCPS. After 
7 days of culture, the samples treated with $\mathrm{O}_{2}$ at $30 \mathrm{~W}$ for $10 \mathrm{~min}$ and with $\mathrm{Ar}$ at $30 \mathrm{~W}$ for 10 and $5 \mathrm{~min}$ are the ones that performed better in terms of cellular proliferation.

Regarding the influence of the different plasma treatments over chondrocytic cell (ATDC5 cell line) behavior, the surfaces modified by $\mathrm{O}_{2}$-plasma at $30 \mathrm{~W}$ for $5 \mathrm{~min}$ and at $20 \mathrm{~W}$ for $10 \mathrm{~min}$, as well as the Ar-treated NFMs at $20 \mathrm{~W}$ for 10 and $5 \mathrm{~min}$, presented significantly higher values of cell viability in the first day of culture $(p<0.01)$ when compared to the viability of ATDC5 observed for untreated PCL NFMs (Figure 9). However, only the treatments by $\mathrm{O}_{2}$ presented significantly higher cellular activity than TCPS $(p<0.01)$. This tendency was kept for longer culture time (3 days) with only the exception of Ar-treated NFMs at $20 \mathrm{~W}$ for $5 \mathrm{~min}$. Moreover, the NFMs treated in Ar atmosphere at $30 \mathrm{~W}$ for $10 \mathrm{~min}$ also presented higher cellular viability than untreated NFMs $(p<0.01)$. In comparison with TCPS, only the $\mathrm{O}_{2}$-treated at $20 \mathrm{~W}$ for $10 \mathrm{~min}$ NFMs presented higher cellular activity $(p<0.01) . \mathrm{O}_{2}$-treated NFMs for a shorter time period $(5 \mathrm{~min})$ showed significantly lower values of cellular activity $(p<0.01)$. The Dunnett's test performed on data obtained after 7 days of culture revealed that the untreated PCL NFMs as well as the ones treated with $\mathrm{O}_{2}$ at $30 \mathrm{~W}$ and $20 \mathrm{~W}$ for $10 \mathrm{~min}$, with Ar at $30 \mathrm{~W}$ for $5 \mathrm{~min}$ and at $20 \mathrm{~W}$ for $5 \mathrm{~min}$ show higher values of cell viability than standard polystyrene $(p<0.01)$, which is a remarkable result. After 14 days of culture, only the plasma treatment with $\mathrm{O}_{2}$ at $30 \mathrm{~W}$ for $5 \mathrm{~min}$ and with $\mathrm{Ar}$ at $20 \mathrm{~W}$ for $5 \mathrm{~min}$ presented higher values of cell viability than untreated PCL NFMs $(p<0.01)$. The treatments with $\mathrm{O}_{2}$ also presented higher cellular activity than TCPS $(p<0.01)$. Taken as a whole, the $\mathrm{O}_{2}$-treated NFMs at $30 \mathrm{~W}$ for 5 min always show a better performance in cell adhesion and proliferation than untreated PCL NFMs for shorter culture periods (up to 3 days). For longer culture periods ( $>7$ days), the Ar-treated NFMs at $20 \mathrm{~W}$ for 5 min demonstrated the support of higher cellular activity.

Concerning the influence of plasma-treatment over the activity of osteoblast-like cells after 1 day of culture, the plasma treatments with $\mathrm{O}_{2}$ at $30 \mathrm{~W}$ for 5 min and Ar at $30 \mathrm{~W}$ for $10 \mathrm{~min}$ induced significantly higher cellular viability than untreated PCL NFMs $(p<0.01)$, but similar to the performance observed for TCPS (Figure 10). After 3 days of culture, the NFMs treated with $\mathrm{O}_{2}$ at $30 \mathrm{~W}$ for $5 \mathrm{~min}$ and $20 \mathrm{~W}$ for $10 \mathrm{~min}$, and $\mathrm{Ar}$ at $30 \mathrm{~W}$ for $10 \mathrm{~min}$ and $20 \mathrm{~W}$ for 5 min presented significantly higher values of cell viability $(p<0.01)$ when compared to untreated NFMs. Those values are well in the range of those observed for standard polystyrene. After 7 days of culture, only the $\mathrm{O}_{2}$-treated NFMs at $30 \mathrm{~W}$ for 5 min and Artreated NFMS at $20 \mathrm{~W}$ for 5 min presented comparable cellular activity to TCPS, as revealed by the Dunnett's test. Those conditions together with the Ar-plasma treatment at $30 \mathrm{~W}$ for $10 \mathrm{~min}$ also presented significantly higher cellular performance than untreated NFMs $(p<0.01)$ for longer time culture periods (14 days). In fact, these plasma treatment conditions presented similar cellular viability to TCPS, demonstrating its suitability for longer cell culturing periods. It could also be observed that the $\mathrm{O}_{2}$-treated NFMs at $30 \mathrm{~W}$ for 5 min were consistently the most effective in all the culturing periods and the NFMs treated with $\mathrm{Ar}$ at $20 \mathrm{~W}$ for $5 \mathrm{~min}$ was also very effective after 3 days of cell culture.

\section{Discussion}

The engineering of nanoscale surfaces allows tailoring the material surface characteristics, which can lead to significant effects upon the cellular behavior. The main advantage of this engineering approach is the ability to design the material surfaces to provide microenvironments closer to the native ECM and thus facilitate cell activity. ${ }^{[23]}$ Theoretically, an optimal substrate for cells should emulate as near as possible the topographical and biochemical nature of the native tissue. In the present study, nanostructured materials with morphologies similar to the native ECM
Figure 9. Box plot of MTS assay results for chondrocytes (ATDC5 cell line) cultured on untreated and plasma-treated PCL NFMs for 1, 3, 7, and 14 days. A) TCPS. B) PCL sovent-cast membrane. C) Untreated PCL NFM. D) $\mathrm{O}_{2}$ at $30 \mathrm{~W}$ for $10 \mathrm{~min}$. E) $\mathrm{O}_{2}$ at $30 \mathrm{~W}$ for $5 \mathrm{~min}$. F) $\mathrm{O}_{2}$ at $20 \mathrm{~W}$ for $10 \mathrm{~min}$. G) $\mathrm{O}_{2}$ at $20 \mathrm{~W}$ for $5 \mathrm{~min}$. H) Ar at $30 \mathrm{~W}$ for $10 \mathrm{~min}$. I) Ar at $30 \mathrm{~W}$ for $5 \mathrm{~min}$. J) Ar at $20 \mathrm{~W}$ for $10 \mathrm{~min}$. K) Ar at $20 \mathrm{~W}$ for $5 \mathrm{~min}$. Data were analyzed nonparametrically by KruskalWallis test followed by Dunnett's test for multiple comparisons. a) $p<0.01$ versus untreated PCL NFM. b) $p<0.01$ versus TCPS. 

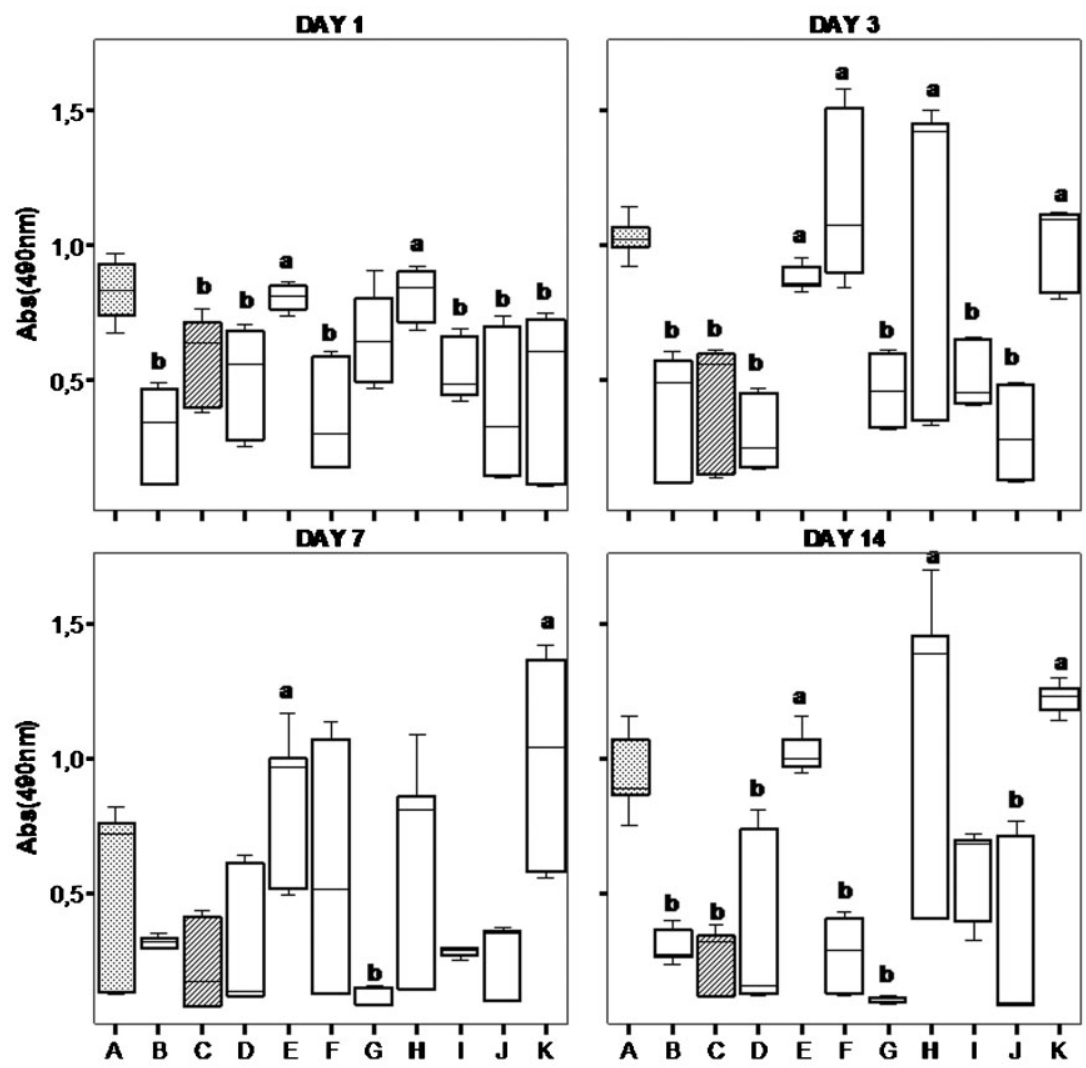

Figure 10. Box plot of MTS assay results for osteoblasts (Saos-2 cell line) cultured on plasma-treated and untreated PCL NFMs for 1, 3, 7, and 14 days. A) TCPS. B) PCL sovent-cast membrane. C) Untreated PCL NFM. D) $\mathrm{O}_{2}$ at $30 \mathrm{~W}$ for $10 \mathrm{~min}$. E) $\mathrm{O}_{2}$ at $30 \mathrm{~W}$ for $5 \mathrm{~min}$. F) $\mathrm{O}_{2}$ at $20 \mathrm{~W}$ for $10 \mathrm{~min}$. G) $\mathrm{O}_{2}$ at $20 \mathrm{~W}$ for $5 \mathrm{~min}$. H) Ar at $30 \mathrm{~W}$ for $10 \mathrm{~min}$. I) Ar at $30 \mathrm{~W}$ for $5 \mathrm{~min}$. J) $\mathrm{Ar}$ at $20 \mathrm{~W}$ for $10 \mathrm{~min}$. K) Ar at $20 \mathrm{~W}$ for $5 \mathrm{~min}$. Data were analyzed nonparametrically by KruskalWallis test followed by Dunnett's test for multiple comparisons. a) $p<0.01$ versus untreated PCL NFM. b) $p<0.01$ versus TCPS.

were produced by electrospinning. Electrospun-processed materials have the potential to generate scaffolds capable of providing ECM-like surfaces, facilitating cell-matrix and cellcell interactions, and therefore being very useful for tissue engineering strategies. However, cells recognize not only topographical clues on the surfaces, but also the surface chemistry, which can significantly influence their behavior. Surface functionalization of biodegradable synthetic polymers has been successfully achieved by plasma treatments, thus decreasing their intrinsic hydrophobicity. ${ }^{[16]}$ However, only recently has the plasma surface modification of $3 \mathrm{D}$ polymerbased structures been considered as an alternative route to enhance their biological performance. The difficulties in the surface modification of scaffolds by plasma are raised by the requirement for highly porous and interconnected samples (the pores must be wider than the mean free path of the electrons and the Debye length ${ }^{[24]}$. Thus, this technique is suitable to modify electrospun structures because of its inherent interconnectivity. Moreover, unlike other physical and chemical surface modification techniques, the plasma action is limited to $10 \mathrm{~nm}$ below the surface and does not affect the bulk properties of the material. ${ }^{[15,17,18,25]}$ The selection of appropriate treatment conditions is very important since the nanosized structure of NFMs should not be compromised, and nor should its cellular performance. Depending on the treatment conditions used, such as the type of gas, pressure, temperature, time of exposure, and intensity (or power), both chemical and some physical characteristics of the surface may be tailored to develop optimal interactions with cells and tissues. ${ }^{[26]}$

The electrospun NFMs subjected to different plasma treatments were morphologically characterized by SEM. This analysis showed that thinner nanofibers were not present in some plasma conditions probably because of polymer melting that could be due to an undesired increment of the reaction chamber temperature or by the electric power used. Other works reported significant morphological alterations induced by plasma surface modification. ${ }^{\text {[27] }}$ The analysis of the morphological alterations was also performed by the characterization of the surface roughness. This analysis may be performed by various techniques such as atomic force microscopy (AFM) or interferometric optical profilometry. The latest was selected in this study because of its ability to scan a larger area than by AFM. Some works in literature ${ }^{[28,29]}$ confirmed an increase in surface roughness after the plasma treatment, due to polymer melting at the surface. This effect increases directly with the duration of the treatment. Recently, Wei et al. ${ }^{[30]}$ modified the surface of electrospun polyamide 6 nanofibers by cold gas plasma treatment and observed that the surface roughness of the fiber was greatly increased when compared to the surface of the untreated fiber. The results obtained in the present study with plasma treatments at low power and exposure time confirm those previous observations. However, for longer treatment times and higher power, a smoothing of the surface nanofibers was observed, which may have been due to the partial polymer melting during the plasma treatment.

Contact angle analysis is a highly sensitive technique for the determination of the surface wettability. Moreover, the surface energy can be quantified using standard polar and nonpolar liquids and some well-established models. However, this test is also dependent on the surface roughness. In fact, the NFMs present a quite rough surface and the data herein reported is particularly valid for comparative purposes. The untreated electrospun PCL NFM is highly hydrophobic (with a measured water contact angle of $\approx 130^{\circ}$ ). A decrease of the contact angle due to the plasma treatments was observed mainly after the $\mathrm{O}_{2}$ treatments. These results demonstrated that plasma treatment is an effective method to increase the surface hydrophilicity of polyester NFMs. Recently, Lai et al. ${ }^{[20]}$ showed that poly(ethylene terephthalate) (PET) smoother surfaces at the microscale led to smaller contact angles. Generally, ${ }^{[19,21]}$ plasma-induced polar chemical groups 
such as oxygen-containing groups tend to increase the surface energy of the polymers and thus enhance their hydrophilic behavior. $\mathrm{O}_{2}$-plasma treatment is commonly used to introduce those functional groups at the nanofiber surface. ${ }^{[19]}$ It has been shown already that much of the oxidation is caused by radical reactions between the polymer chain backbone and atomic oxygen in the plasma, leading to various functionalities such as hydroperoxides, carbonyls, carboxylic acids, and peracids. ${ }^{[31]}$ A higher content of oxygen-containing groups (namely, $-\mathrm{O}-\mathrm{H}$ and $-\mathrm{C}=\mathrm{O}$ ) were detected by XPS in our plasma-treated electrospun PCL NFMs. As previously stated, these changes result in a significant increase in the hydrophilicity of the surfaces. Indeed, Lai et al. ${ }^{[20]}$ stated that the $\mathrm{C}=\mathrm{O}$ bond is the main factor controlling the hydrophilicity of polymer surfaces. Although Ar is an inert gas, plasma-treatment with this gas can also introduce oxygen-containing functionality at the surface. ${ }^{[20]}$ This effect is caused by reaction between the free radicals at the surface created during the treatment and the oxygen existing in the air.

As previously mentioned, the main purpose of this work was to define conditions of the treatment that result in surfaces favorable for cell growth. We have used different cell types (i.e., fibroblasts, chondrocytes, and osteoblasts) to validate the efficacy of a defined plasma-treatment. Among the plasmatreated electrospun NFMs, the ones modified in an $\mathrm{O}_{2}$ atmosphere at $30 \mathrm{~W}$ for $5 \mathrm{~min}$ and with $\mathrm{Ar}$ at $20 \mathrm{~W}$ for $5 \mathrm{~min}$ can be classified as optimal substrates for the cell adhesion and proliferation. The NFMs treated at those conditions show similar cell viability as the one observed for TCPS. In the case of $\mathrm{O}_{2}$-modified NFM at $30 \mathrm{~W}$ for $5 \mathrm{~min}$, we believe that the observed cellular activity is mainly due to the increased hydrophilic character of the NFM (glycerol contact angle $\approx 30^{\circ}$ ). Similar results were observed for human skin fibroblasts whose spreading increased along chemically characterized gradient surfaces going from the most hydrophobic toward the hydrophilic end. ${ }^{[32]}$ Among the hydrophilic surfaces, differences in charge and wettability significantly influence cell attachment but not spreading or cytoskeleton organization. Surface hydrophilicity $\left(20^{\circ}-40^{\circ}\right.$ water contact angle) is the major parameter promoting high levels of cell attachment. ${ }^{[33]}$ However, another study demonstrated that the maximum adhesion and growth of various cell types (ovary, fibroblast, and endothelial cells) on polymer surfaces with a wettability gradient appeared around water contact angles of $55^{\circ}{ }^{[34]}$ Therefore, the optimum value of the contact angle for optimal cell adhesion is somewhat inconclusive in the literature, varying between $20^{\circ}$ and $70^{\circ}$.

The samples treated at these conditions also presented the highest oxygen content (XPS analysis), indicating the importance of the surface chemistry for cell adhesion. The oxygen atoms at the surface may be part of the carbonyl, carboxyl, ester, or hydroxyl groups. ${ }^{[35]}$ However, it is not clear which of these groups is the most effective in influencing the cell-biomaterial interaction. It has been suggested ${ }^{[36]}$ that the oxygen from the carboxyl group is more effective in promoting this interaction, while the oxygen derived from the ester and hydroxyl groups is less effective. However, authors suggested that the presence of hydroxyl groups was beneficial for cell adhesion. ${ }^{[37]}$ Furthermore, a selective blocking of the hydroxyl groups was shown to result in the inhibition of the adhesion of baby hamster kidney cells or leukocytes, while blocking the carboxyl groups did not affect cell adhesion. ${ }^{[38]}$

The NFMs treated in an Ar atmosphere at $20 \mathrm{~W}$ for $5 \mathrm{~min}$ presented a more hydrophobic character (glycerol contact angle $\approx 110^{\circ}$ ), most probably because of the surface roughness observed for this treated NFM. It was stated previously that surface topography is a key factor affecting cellular morphology, proliferation, and differentiation. ${ }^{[23]}$ Our experimental results also confirm many reports describing an increased proliferation of osteoblastic cells on rough substrata. ${ }^{[39,40]}$ However, it is also possible to find reports where it is demonstrated that the surface roughness negatively affects the adhesion, proliferation, and differentiation of different cell types, namely osteoblasts and chondrocytes. ${ }^{[41]}$ Furthermore, SEM micrographs of bone cells on biomaterials with different surface roughnesses generally demonstrate that the cell spreading and monolayer formation was more effective on smoother surfaces. ${ }^{[42]}$ In the case of fibroblastic cells, there are many studies demonstrating the slower cell proliferation on rough substrates compared to smooth surfaces. ${ }^{[29,40,43]}$ Thus, we may say that the effect or influence of the surface roughness on the cell adhesion and proliferation is not consensual in the literature.

Many authors write that the NFMs are morphologically similar with the ECM of many tissues and that this similarity must enhance the cell behavior at the surface of those structures. Herein, we showed that the surface chemistry has, at least, as strong of an effect over cell activity as the structural morphology of the NFMs. Thus, we propose that the performance of NFMs also requires chemical surface optimization.

\section{Conclusions}

Electrospun PCL NFMs were submitted to different plasma treatments including the gas used $\left(\mathrm{O}_{2}\right.$ and $\left.\mathrm{Ar}\right)$, the electrical power, and the exposure time. The goal was to obtain enhanced cellular response at the surface of NFMs by adjusting the treatment conditions. SEM micrographs and surface roughness analysis demonstrated the induction of topographical alterations by the plasma treatments. The contact angle analysis revealed that the electrospun NFMs became generally more hydrophilic after the applied modifications. The most significant changes in the wettability were observed for $\mathrm{O}_{2}$-treated NFMs. XPS results indicated higher oxygen-contents at the surface of plasma-treated NFMs, including hydroxyl $(-\mathrm{OH})$ and carbonyl $(-\mathrm{C}=\mathrm{O})$ functionalities. However, the relative content of these functional groups was dependent on the specific conditions used.

Different cell types, namely fibroblasts (L929 cell line), chondrocytes (ATDC5 cell line), and osteoblast-like (Saos-2) cells, adhered and proliferated at the surface of plasma-treated nanofibrous structures. It was possible to define treatment conditions leading to enhanced cell adhesion and faster proliferation, namely $\mathrm{O}_{2}$ at $30 \mathrm{~W}$ for $5 \mathrm{~min}$ and $\mathrm{Ar}$ at $20 \mathrm{~W}$ for $5 \mathrm{~min}$. Using those conditions, both the hydrophilic behavior and the roughness of the NFM surfaces were affected. 
Therefore, both those plasma treatment conditions could be further applied in the development of biomaterials with enhanced biological performance independently of the tissue to be regenerated.

It was shown that one treatment with $\mathrm{O}_{2}$ and one with $\mathrm{Ar}$ outperform significantly the other treatment conditions and also the untreated NFMs. Our results show that the biological performance of NFMs can be improved by the careful control of its surface properties without compromising significantly the overall morphology of the nanofibers.

\section{Experimental Section}

Electrospinning Process: A polymeric solution of $17 \% \mathrm{w} / \mathrm{v} \mathrm{PCL}$ (TONE ${ }^{\text {TM }}$, Union Carbide Chemicals and Plastics Division; New Jersey) was prepared using an organic solvent mixture composed of chloroform (Aldrich; Germany) and $\mathrm{N}, \mathrm{N}$-dimethylformamide (Aldrich) (7:3 ratio). The solution was electrospun at $9-10 \mathrm{kV}, \mathrm{a}$ needle-to-ground collector distance of $20 \mathrm{~cm}$, and a flow rate of $1.0 \mathrm{~mL} \mathrm{~h}^{-1}$. The nonwoven fibrous meshes were collected on a flat aluminum foil and the solvent evaporation was performed at room temperature during at least 2 days.

Surface Modification by Plasma Treatment: The PCL NFMs obtained by electrospinning were modified by plasma treatment. The treatment was performed in a PlasmaPrep 5 reactor (GaLa Instrumente, Germany) with a chamber size of $15-\mathrm{cm}$ diameter and $31-\mathrm{cm}$ length (volume $5 \mathrm{~L}$ ) and with fully automated process control. The samples were clamped between both electrodes and the chamber was evacuated. Two different gases $\left(\mathrm{O}_{2}\right.$ or $\left.\mathrm{Ar}\right)$ were used and the chamber was filled with the working gas five times prior to the treatment. A radio frequency (RF) source operating at $13.56 \mathrm{mHz}$ was used and the power intensity (20 or $30 \mathrm{~W}$ ) was applied for either 5 or $10 \mathrm{~min}$. The pressure of the plasma chamber was kept at $0.2 \mathrm{mbar}$ in all conditions by controlling the working gas flow. When the higher power level $(30 \mathrm{~W})$ and longer treatment time $(10 \mathrm{~min})$ were used as working conditions, an increase of the temperature inside the chamber was observed $\left(\approx 35^{\circ} \mathrm{C}\right)$.

Surface Characterization of Untreated and Plasma-Treated PCL Nanofiber Meshes: SEM: Untreated and plasma-treated electrospun PCL NFMs were sputter-coated with gold (Fisons Instruments, model SC502; England) for $2 \mathrm{~min}$ at $15 \mathrm{~mA}$. The samples were further analyzed by SEM (Leica Cambridge, model S360; England).

Interferometric Optical Profilometry: The surface topography of the untreated and plasma-treated electrospun PCL NFMs was assessed by noncontact profilometry using an interferometer profiler (Wyko-Veeco, model NT1100; USA) equipped with the WycoVision ${ }^{\circledR} 32$ analytical software. Topographic roughness parameters average roughness $\left(R_{\mathrm{a}}\right)$ and root mean square (RMS) roughness $\left(R_{\mathrm{q}}\right)$ were both determined for each sample. Each sample was evaluated, at least, at two randomly selected and representative specimen locations.

Contact Angle Measurements: The static contact angles were measured at room temperature with a Contact Angle Equipment (DataPhysics Instruments, model OCA 15plus; Germany). The values were obtained by the sessile drop method. The used liquids (water and glycerol, HPLC grade, $3 \mu \mathrm{L}$ ) were applied by a motor driven syringe at different zones of each sample and the measurement time was extended until $5 \mathrm{~min}$. At least five measurements were carried out for each sample and the presented data are averaged values for those measurements.

XPS: Analysis of the untreated and plasma-modified electrospun NFMs was performed using an VG Escalab 250 iXL ESCA instrument (VG Scientific; UK), equipped with Al-K $\alpha$ 1,2 monochromatized radiation at $1486.92 \mathrm{eV}$ in the X-ray source. Due to the nonconductive nature of the samples, it was necessary to use an electron flood gun to minimize the surface charging accumulation. The neutralization of the surface charge was performed by using both a low energy flood gun (electrons in the range of 0.00 $14.00 \mathrm{eV}$ ) and an electrically grounded stainless steel screen was placed directly at the sample surface.

The XPS measurements were carried out using monochromatic Al- $K \boldsymbol{\alpha}$ radiation $(h \boldsymbol{v}=1486.92 \mathrm{eV})$. Photoelectrons were collected from a takeoff angle of $90^{\circ}$ relative to the sample surface. The measurement was performed in a constant analyzer energy mode (CAE) with $100.00 \mathrm{eV}$ pass energy for the screening stage and $20.00 \mathrm{eV}$ pass energy to obtain high resolution spectra.

Charge referencing was carried out by setting the lower binding energy $\mathrm{C} 1 \mathrm{~s}$ hydrocarbon $(\mathrm{CHx})$ peak at $285.00 \mathrm{eV}$. The spectra fitting is based on a $\chi$-squared algorithm used to determine the effectiveness of the peak fit. Surface elemental composition was determined using the standard Scofield photoemission cross section.

Biological Assays: Cell Lines: Three types of cell lines were used: L929, a mouse lung fibroblastic cell line; the Saos-2, a Human primary osteosarcoma cell line; and the ATDC5, a mouse condrocyte teratocarcinoma-derived cell line, all supplied by European Collection of Cell Cultures (ECACC; UK). L929 and Saos-2 cells were maintained in Dulbecco's Modified Eagle's Medium (DMEM) (Sigma-Aldrich; Germany) supplemented with $10 \%$ heat-inactivated fetal bovine serum (Biochrom AG; Germany) and $1 \%$ antibiotic-antimycotic solution (Gibco; GB). ATDC5 cells were cultured in DMEM-F12 (Gibco; GB) supplemented with $10 \%$ heat-inactivated fetal bovine serum (Biochrom $A G$ ) and $2 \mathrm{~mm} \mathrm{L-}$ glutamine (Sigma-Aldrich). All cell types were cultured in a humidified incubator at $37^{\circ} \mathrm{C}$, in $5 \% \mathrm{CO}_{2}$ atmosphere. The media were routinely replaced every $2-3$ days.

Cell Seeding: Prior to the biological assays, the untreated and plasma-modified PCL NFMs were sterilized by ethylene oxide. The sterile samples of NFMs and controls, PCL solvent-cast membranes, and TCPS coverslips, were placed in 24-well cell culture plates (Costar ${ }^{\mathbb{R}}$, Corning; NY). A $50 \mu \mathrm{L}$ cell suspension containing $1 \times 10^{5}$ cells was added to each $\mathrm{cm}^{2}$ of each sample and controls. The biological parameters were assessed at different culture periods: $1,3,7$, and 14 days.

Evaluation of Cell Morphology: To evaluate the cell adhesion and morphology, the constructs (cells-NFMs) were fixed with $2.5 \%$ glutaraldehyde (Sigma; USA) in phosphate buffer saline (Sigma) solution, for $1 \mathrm{~h}$ at $4^{\circ} \mathrm{C}$. The samples were further dehydrated through a graded series of ethanol and coated in a gold sputter coating equipment (Fisons Instruments, model SC502; England) for $2 \mathrm{~min}$ at $15 \mathrm{~mA}$, and analyzed by SEM (Leica Cambridge, model S360; England). 
Metabolic Activity Analysis (MTS Assay): At each defined culture period, cell viability and proliferation was determined using the CellTiter $96^{\circledR} \mathrm{AQ}_{\text {ueous }}$ One Solution Cell Proliferation Assay (Promega; USA). Briefly, this assay is based on the bioreduction of a tetrazolium compound, 3-(4,5-dimethylthiazol2-yl)-5-(3-carboxymethoxyphenyl)-2-(4-sulfofenyl)-2H-tetrazolium (MTS), into a brown formazan product that is soluble in water. This conversion is accomplished by the production of nicotinamide adenine dinucleotide phosphate (NADPH) or nicotinamide adenine dinucleotide (NADH) by the dehydrogenase enzymes existing in metabolically active cells. The absorbance relative to the quantity of formazan product is directly proportional to the number of living cells in culture, and was measured at $490 \mathrm{~nm}$ in a microplate reader (Bio-Tek, model Synergie HT; USA). Three specimens per condition and per time point were characterized.

Statistical Analysis: Statistical analysis was performed using the SPSS statistic software (Release 8.0.0 for Windows). Firstly, a Shapiro-Wilk test was used to ascertain about the normality of the data and the results showed that the data was not following a normal distribution. For this reason, a Kruskal-Wallis test followed by Dunnett's test for multiple comparisons was performed to analyze the effect of the various plasma treatments performed on material the hydrophilicity and cellular performance. The $p$-values lower than 0.01 were considered statistically significant in the analysis of the results.

\section{Acknowledgements}

This work was partially supported by the European Integrated Project GENOSTEM (LSH-STREP-CT-2003-503161) and the European Network of Excellence EXPERTISSUES (NMP3-CT2004-500283). The Portuguese Foundation for Science and Technology for the project Naturally Nano (POCI/EME/58982/ 2004) and the Ph.D. grant of A. Martins (SFRH/BD/24382/2005) is also acknowledged.

[1] J. A. Hubbell, Nat. Biotechnol. 1995, 13, 565.

[2] J. F. Mano, G. A. Silva, H. S. Azevedo, P. B. Malafaya, R. A. Sousa, S. S. Silva, L. F. Boesel, J. M. Oliveira, T. C. Santos, A. P. Marques, N. M. Neves, R. L. Reis, J. R. Soc. Interface 2007, 4, 999.

[3] C. M. Agrawal, R. B. Ray, J. Biomed. Mater. Res. 2001, 55, 141.

[4] C. G. Pitt, M. M. Gratzl, G. L. Kimmel, J. Surles, A. Schindler, Biomaterials 1981, 2, 215.

[5] H. Tsuji, Y. Ikada, J. Appl. Polym. Sci. 1998, 67, 405.

[6] a) G. Ciapetti, L. Ambrosio, L. Savarino, D. Granchi, E. Cenni, N. Baldini, S. Pagani, S. Guizzardi, F. Causa, A. Giunti, Biomaterials 2003, 24, 3815; b) D. W. Hutmacher, K. W. Ng, C. Kaps, M. Sittinger, S. Klaring, Biomaterials 2003, 24, 4445; c) X. X. Shao, D. W. Hutmacher, S. T. Ho, J. C. Goh, E. H. Lee, Biomaterials 2006, 27, 1071.

[7] H. Tsuji, Y. Ikada, J. Appl. Polym. Sci. 1996, 60, 2367.

[8] a) R. Dersch, M. Steinhart, U. Boudriot, A. Greiner, J. H. Wendorff, Polym. Adv. Technol. 2005, 16, 276; b) Z. M. Huang, Y. Z. Zhang, M. Kotaki, S. Ramakrishna, Compos. Sci. Technol. 2003, 63, 2223.

[9] A. Martins, J. V. Araujo, R. L. Reis, N. M. Neves, Nanomedicine 2007, 2, 929.
[10] J. Zeng, X. Chen, X. Xu, Q. Liang, X. Bian, L. Yang, X. Jing, J. Appl. Polym. Sci. 2003, 89, 1085.

[11] D. H. Reneker, I. Chun, Nanotechnology 1996, 7, 216.

[12] a) Z. Ma, M. Kotaki, R. Inai, S. Ramakrishna, Tissue Eng. 2005, 11, 101; b) L. A. Smith, P. X. Ma, Colloids Surf. B 2004, 39, 125

[13] a) K. Fujihara, M. Kotaki, S. Ramakrishna, Biomaterials 2005, 26, 4139; b) W. J. Li, K. G. Danielson, P. G. Alexander, R. S. Tuan, J. Biomed. Mater. Res. A 2003, 67, 1105; c) W. J. Li, R. Tuli, X. Huang, P. Laquerriere, R. S. Tuan, Biomaterials 2005, 26, 5158; d) B. M. Min, G. Lee, S. H. Kim, Y. S. Nam, T. S. Lee, W. H. Park, Biomaterials 2004, 25, 1289; e) C. Xu, R. Inai, M. Kotaki, S. Ramakrishna, Tissue Eng. 2004, 10, 1160; f) F. Yang, C. Y. Xu, M. Kotaki, S. Wang, S. Ramakrishna, J. Biomater. Sci. 2004, 15, 1483.

[14] K. Tuzlakoglu, N. Bolgen, A. J. Salgado, M. E. Gomes, E. Piskin, R. L. Reis, J. Mater. Sci. Mater. Med. 2005, 16, 1099.

[15] C. M. Chan, T. M. Ko, H. Hiraoka, Surf. Sci. Rep. 1996, $24,1$.

[16] S. Wang, W. Cui, J. Bei, Anal. Bioanal. Chem. 2005, 381, 547.

[17] P. K. Chu, J. Y. Chen, L. P. Wang, N. Huang, Mater. Sci. Eng. Rep. 2002, 36, 143

[18] a) M. Ibnabddjalil, I. H. Loh, C. C. Chu, N. Blumenthal, H. Alexander, D. Turner, J. Biomed. Mater. Res. 1994, 28, 289; b) I. H. Loh, H. L. Lin, C. C. Chu, J. Appl. Biomater. 1992, 3, 131.

[19] N. Y. Cui, N. M. D. Brown, Appl. Surf. Sci. 2002, 189, 31.

[20] J. Lai, B. Sunderland, J. Xue, S. Yan, W. Zhao, M. Folkard, B. D. Michael, Y. Wang, Appl. Surf. Sci. 2006, 252, 3375.

[21] E. M. Liston, L. Martinu, M. R. Wertheimer, J. Adhes. Sci. Technol. 1993, 7, 1091

[22] D. Briem, S. Strametz, K. Schroder, N. M. Meenen, W. Lehmann, W. Linhart, A. Ohl, J. M. Rueger, J. Mater. Sci. Mater. Med. 2005, 16, 671.

[23] R. G. Flemming, C. J. Murphy, G. A. Abrams, S. L. Goodman, P. F. Nealey, Biomaterials 1999, 20, 573.

[24] A. Holländer, Surf. Coat. Technol. 2005, 200, 561.

[25] S. C. Baker, N. Atkin, P. A. Gunning, N. Granville, K. Wilson, D. Wilson, J. Southgate, Biomaterials 2006, 27, 3136.

[26] Z. Gugala, S. Gogolewski, J. Biomed. Mater. Res. A 2006, 76, 288.

[27] K. Park, Y. M. Ju, J. S. Son, K. D. Ahn, D. K. Han, J. Biomater. Sci. 2007, 18, 369.

[28] Y. Wan, X. Qu, J. Lu, C. Zhu, L. Wan, J. Yang, J. Bei, S. Wang, Biomaterials 2004, 25, 4777.

[29] J. Yang, J. Bei, S. Wang, Biomaterials 2002, 23, 2607.

[30] Q. F. Wei, W. D. Gao, D. Y. Hou, X. Q. Wang, Appl. Surf. Sci. 2005, $245,16$.

[31] L. Lianos, C. Quet, T. M. Duc, Surf. Interface Anal. 1994, 21, 14.

[32] T. Groth, G. Altankov, Biomaterials 1996, 17, 1227.

[33] K. Webb, V. Hlady, P. A. Tresco, J. Biomed. Mater. Res. 1998, 41, 422.

[34] J. H. Lee, G. Khang, J. W. Lee, H. B. Lee, J. Colloid Interface Sci. 1998, 205, 323.

[35] S. Haiber, X. Ai, H. Bubert, M. Heintze, V. Bruser, W. Brandl, G. Marginean, Anal. Bioanal. Chem. 2003, 375, 875.

[36] E. A. Vogler, R. W. Bussian, J. Biomed. Mater. Res. 1987, 21, 1197.

[37] J. H. Lee, H. B. Lee, J. Biomater. Sci. 1993, 4, 467.

[38] A. S. Curtis, J. V. Forrester, C. McInnes, F. Lawrie, J. Cell Biol. 1983, 97, 1500.

[39] a) I. Degasne, M. F. Basle, V. Demais, G. Hure, M. Lesourd, B. Grolleau, L. Mercier, D. Chappard, Calcif. Tissue Int. 1999, 64, 499; b) K. Hatano, H. Inoue, T. Kojo, T. Matsunaga, T. Tsujisawa, C. Uchiyama, Y. Uchida, Bone 1999, 25, 439; c) J. Lincks, B. D. Boyan, C. R. Blanchard, C. H. Lohmann, Y. Liu, D. L. Cochran, D. D. Dean, Z. Schwartz, Biomaterials 1998, 19, 2219; d) O. Zinger, G. Zhao, Z. Schwartz, J. Simpson, M. Wieland, D. Landolt, B. Boyan, Biomaterials 2005, 26, 1837.

[40] T. P. Kunzler, T. Drobek, M. Schuler, N. D. Spencer, Biomaterials 2007, 28, 2175.

[41] a) K. Anselme, M. Bigerelle, B. Noel, E. Dufresne, D. Judas, A. lost, P. Hardouin, J. Biomed Mater. Res. 2000, 49, 155; b) K. Anselme, 
P. Linez, M. Bigerelle, D. Le Maguer, A. Le Maguer, P. Hardouin, H. F. Hildebrand, A. lost, J. M. Leroy, Biomaterials 2000, 21, 1567; c) B. D. Boyan, J. Lincks, C. H. Lohmann, V. L. Sylvia, D. L. Cochran, C. R. Blanchard, D. D. Dean, Z. Schwartz, J. Orthop. Res. 1999, 17, 446; d) J. Y. Martin, Z. Schwartz, T. W. Hummert, D. M. Schraub, J. Simpson, J. Lankford, Jr, D. D. Dean, D. L. Cochran, B. D. Boyan, J. Biomed. Mater. Res. 1995, 29, 389; e) Z. Schwartz, J. Y. Martin, D. D. Dean, J. Simpson, D. L. Cochran, B. D. Boyan, J. Biomed. Mater. Res. 1996, 30, 145.
[42] K. Anselme, M. Bigerelle, J. Mater. Sci. Mater. Med. 2006, 17, 471.

[43] a) B. Grossner-Schreiber, M. Herzog, J. Hedderich, A. Duck, M. Hannig, M. Griepentrog, Clin. Oral Implants Res. 2006, 17, 736; b) M. Kononen, M. Hormia, J. Kivilahti, J. Hautaniemi, I. Thesleff, J. Biomed. Mater. Res. 1992, 26, 1325.

Received: November 6, 2008

Published online: February 25, 2009 